\title{
What to eat if there are no fruits in the forest? The food of Muscardinus avellanarius in non-typical habitats (Rodentia: Gliridae)
}

Čím se živit nejsou-li v lese žádné plody? Potrava plšíka lískového (Muscardinus avellanarius) v netypickém biotopu (Rodentia: Gliridae)

\section{Sven BÜCHNER ${ }^{1,2}$, Nicolle BRÄSEL ${ }^{2} \&$ Irmhild WOLZ ${ }^{3}$}

${ }^{1}$ Consultancy for Nature Conservation, Ortsstraße 174, D-02829 Markersdorf, Germany; muscardinus@gmx.net

${ }^{2}$ Senckenberg Museum für Naturkunde Görlitz, Postfach 300 154, D-02806 Görlitz, Germany nicolle84@gmx.net

${ }^{3}$ Kreuzstraße 5, D-91077 Neunkirchen, Germany; irmhild.wolz@wolz-ofr.de

received on 6 June 2018

\begin{abstract}
Faeces of the hazel dormouse (Muscardinus avellanarius) were collected from two forests dominated by Norway spruce (Picea abies) and three by European beech (Fagus sylvatica) for comparison with faeces from a species-rich broad-leafed forest. Samples were analysed under the microscope. At the species-rich forest the hazel dormice consumed inflorescences, acorns from the previous year, fungi and arthropods in spring, fruits (soft mast) in summer and hard mast in the autumn. As expected, there was no, or nearly no, soft mast in the hazel dormouse diet in the beech and spruce forests. The main food sources were inflorescences, seeds, arthropods and a rather high percentage of vegetative plant material. Besides the remains of insects from eight orders, we also found spiders (Araneae), harvesters (Opiliones) and centipedes (Chilopoda) as prey of hazel dormice. Hazel dormice can feed in beech woods on beech nuts in the autumn. However, it is not yet clear how they are able to gain weight in spruce dominated forests.
\end{abstract}

Key words. Hazel dormouse, diet, Fagus sylvatica and Picea abies forests.

\section{INTRODUCTION}

The hazel dormouse (Muscardinus avellanarius) is often described as a species with special habitat needs. Typical hazel dormouse habitats should have a high diversity of shrubs. Besides a botanical diversity, the presence of unshaded understorey was the most significant factor in explaining hazel dormouse densities in England (BRIGHT \& MorRis 1990, BRIGHT \& Morris 1996). Unshaded understorey produces more flowers, berries and seeds, which are the important food sources for the hazel dormouse in the course of the year (JUŠKAITIS \& BALTRŪNAITĖ 2013, CHANIN et al. 2015). BRIGHT \& MoRRIs (1996) therefore emphasise the need for active woodland management to keep a vital shrub layer ensuring a continuous food supply for hazel dormice.

In contrast to this situation, stable populations of the species were found with comparably high abundances in pure European beech (Fagus sylvatica) or Norway spruce (Picea abies)

This contribution has been presented at the 10th International Dormouse Conference held at the University of Liège, Belgium, on 11-15 September 2017 
Table 1. Vegetation characteristics and number of samples at study sites for hazel dormouse diet in Saxony and Hesse (Germany); $\mathrm{S}=$ site; $\mathrm{C}=$ cover of shrub layer; $\mathrm{N}=$ number of collected hazel dormouse faeces; $A=$ reference site

Tab. 1. Vegetační charakteristiky a počet vzorků na lokalitách výzkumu potravy plšíka lískového v Sasku a Hesensku (Německo); $\mathrm{S}=$ lokalita; $\mathrm{C}=$ keřový pokryv; $\mathrm{N}=$ počet sebraných pelet plšího trusu; $\mathrm{A}=$ referenční lokalita

\begin{tabular}{lll}
\hline $\mathrm{S}$ forest type / lesní typ & $\mathrm{C} \quad \begin{array}{l}\text { flowering and fruiting shrub/tree species } \\
\text { / kvetoucí a zrající plody dřevin }\end{array}$ & $\mathrm{N}$
\end{tabular}

A species rich broad-leafed standard $\quad 30 \% \quad$ Fraxinus excelsior, Prunus avium, Fagus $\quad 304$ / druhově bohatý listnatý les Sylvatica, Quercus robur, Ulmus glabra,

Picea abies, Carpinus betulus, Salix aurita, Betula pendula, Sorbus aucuparia, Corylus avellana, Crataegus monogyna, Prunus spinosa, Rubus fruticosus, R. idaeus

B spruce forest / smrkový les *6\% Picea abies, Fagus sylvatica, Vaccinium myrtillus 88

C spruce forest/smrkový les

17\% Picea abies, only a few old trees of Fagus 11 sylvatica, Vaccinium myrtillus, Rubus idaeus

D beech forest / bukový les

2\% Fagus sylvatica, Salix sp., Quercus robur $\quad 27$

E beech forest and spruce on the

13\% Fagus sylvatica, Picea abies, Sorbus aucuparia, 39 edges / bukový les se smrkem Betula pendula, Vaccinium myrtillus, Rubus idaeus na okraji

F beech forest and spruce on the edges 7\% Fagus sylvatica, Picea abies, Sorbus aucuparia, / bukový les se smrkem na okraji

Betula pendula, Vaccinium myrtillus, Rubus idaeus, R. fruticosus

* only / pouze Vaccinium myrtillus

forests with little or no shrub layer at all in central Germany (STORCH 1978, BüchNER \& LANG 2014). What are the food resources for the hazel dormouse in such habitats? Can arthropods substitute for the lack of fruits? To answer these questions, we chose a species-rich hazel dormouse habitat and five sites without understorey to study and compare the diet composition over one season.

\section{MATERIAL AND METHODS}

The study area includes six sites of different forest types in the German federal states of Saxony and Hesse (Table 1). Two sites (B and C) are Norway spruce forests at an altitude of approximately $800 \mathrm{~m} \mathrm{a}$. s. 1 . as parts of large forest complexes (more than 1,000 ha) of the same vegetation type (Fig. 1). Spruce is the dominating tree and only few deciduous trees are mixed in. The shrub layer is sparse and because of the tree shade, only rarely flowering and fruiting. Three sites (D, E and F) are dominated by European beech and a little shrub layer or almost none at all (Fig. 2). Only a few woody species are mixed in, mainly Norway spruce. The sites are situated between 330 and $700 \mathrm{~m}$ a. s. 1 . and are also parts of extensive forest complexes. Sites B to F were supplied with 60 to 100 nest boxes at $50 \mathrm{~m}$ intervals.

We chose a species-rich broad-leafed forest in East Saxony as the reference site (site A). This woodland of 15 ha is nearly isolated in the agricultural landscape and was formerly partly used as coppice-with-standards. The tree layer is diverse with more than ten species of different age and height. The shrub 

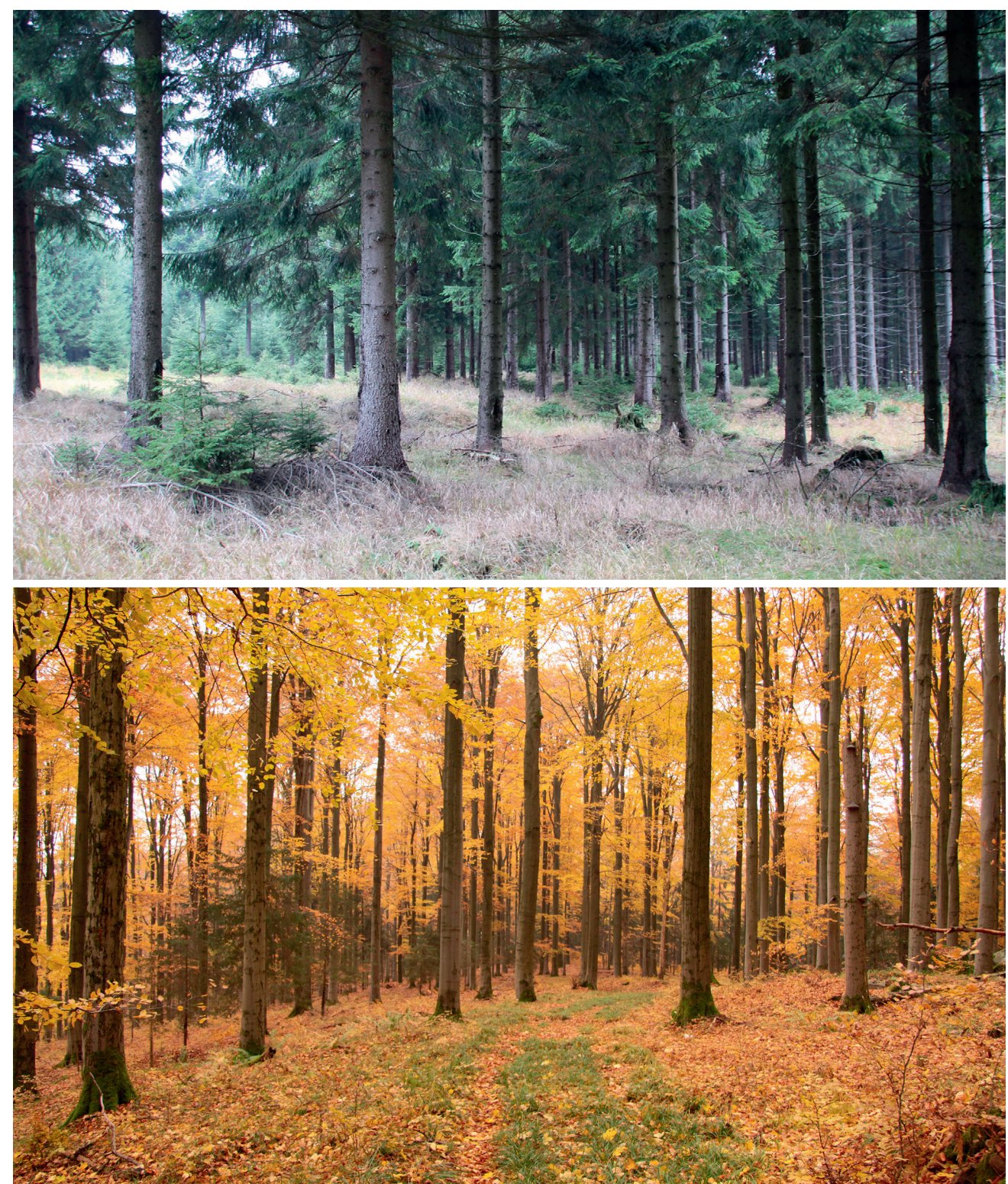

Figs. 1, 2. Hazel dormouse habitats; top - habitat dominated by Norway spruce (sample site B) in the Ore mountains in Saxony; below - habitat dominated by European beech (sample site E) in the Vogtland mountains in Saxony. Photos by S. BüchNER.

Obr. 1, 2. Biotopy plšíka lískového; nahoře - biotop s převahou smrku ztepilého (zkoumaná lokalita B) v saské části Krušných hor; dole - biotop s převahou buku lesního (zkoumaná lokalita E) ve Fojtských horách v Sasku. Obě fota S. BüchNER. 
layer is well expressed and, in a third of the study site, very dense. Study site A is situated at $350 \mathrm{~m} \mathrm{a.} \mathrm{s.} 1$. Here, we checked the 100 nest boxes every fortnight from April to November 2016. All other sites were checked by volunteers in May/June and September/October. The nest boxes at study site A were intensively searched for faeces at every check and therefore the temporal resolution is precise. Due to three to four nest box inspections per site and year, the seasonal classification is not fully correct for all samples for sites B to F. If a nest box was empty during the check in mid-June and the next check followed in September, some samples from the early season were classified from autumn, e.g. when hazel dormice occupied the nest box only at the end of June. Thus, the Figs. 4 and 5 must be carefully interpreted for the seasonal aspects.

During each nest box inspection, all hazel dormouse faeces were collected in Eppendorf tubes and later dried at room temperature. Every dropping was treated as a single sample. The faeces were cut in two pieces and one half was left for further studies. The procedure for the other half followed the method described by JUŠKAITIS et al. (2016): the sample was placed on glass, soaked with water and carefully examined under the microscope at a magnification of $\times 40-400$. Food remains of plants were identified by comparison to a reference collection obtained from fresh potential food samples and hazel dormouse feeding experiments in captivity. For pollen, we used the identification key by BEUG (2015) and for whole plant seeds the digital atlas by CAPPERS et al. (2006).

We tried to identify the diet to species level. For further analysis the food remains were grouped into the types: inflorescences (pollen), soft mast (berries), hard mast (hazel and beech nuts, acorns), vegetative material (plant fibres), fungi (spores), and arthropods. As a rule, a dropping fully consisted of one type of food. We estimated the frequency of occurrence by dividing the number of samples with one type of food by the total number per site and season.

\section{RESULTS}

At the species-rich forest (site A), the hazel dormice consumed a diverse range of inflorescences of Norway spruce, common hawthorn (Crataegus monogyna), willow (Salix sp.), common oak (Quercus robur) and European beech in May and June. Additionally, hazel dormice fed on acorns from the previous year, fungi and arthropods. Fungi dominated the diet during the first half and arthropods in the second half of June. Over the summer from July onwards, the main food source was fruits, mainly of rowan (Sorbus aucuparia) and hawthorn. Raspberries (Rubus idaeus), black berries (R. fruticosus agg.) and sloe (Prunus spinosa) were also consumed but were of less importance. The autumn food was acorns and beech nuts (Fig. 3).

The hazel dormouse diet in the spruce dominated forests (sites B and C) contained arthropods and spruce strobili. However, a large proportion of the diet was vegetative plant material. Raspberries formed less than $10 \%$ of occurrence, and no hard mast or fungi were in the samples from these sites (Fig. 4). Soft mast found in one sample in May was also raspberry, however, this dropping must have remained from the previous year, since there were no fruits yet available at this time of year.

The samples from the beech forests (sites D, E and F) contained vegetative plant material and inflorescences mainly of beech and, in a smaller proportion, spruce and willow. Hard mast (beech nuts) and arthropods were also in the samples and for one site fungi too. We did not detect soft mast in the hazel dormouse faeces from these sites (Fig. 5).

Hazel dormice seem not to be selective in predating arthropods. In the faeces we found remains of the orders Opiliones, Araneae, Chilopoda and of eight insect orders: Neuroptera, Coleoptera, Diptera, Heteroptera, Homoptera, Hymenoptera, Aphidina and Lepidoptera. Harvesters (Opiliones) were rather frequent in the samples and among the insects we found mainly weevils (Curculionidae), butterfly caterpillars, flies, bugs and aphids. 


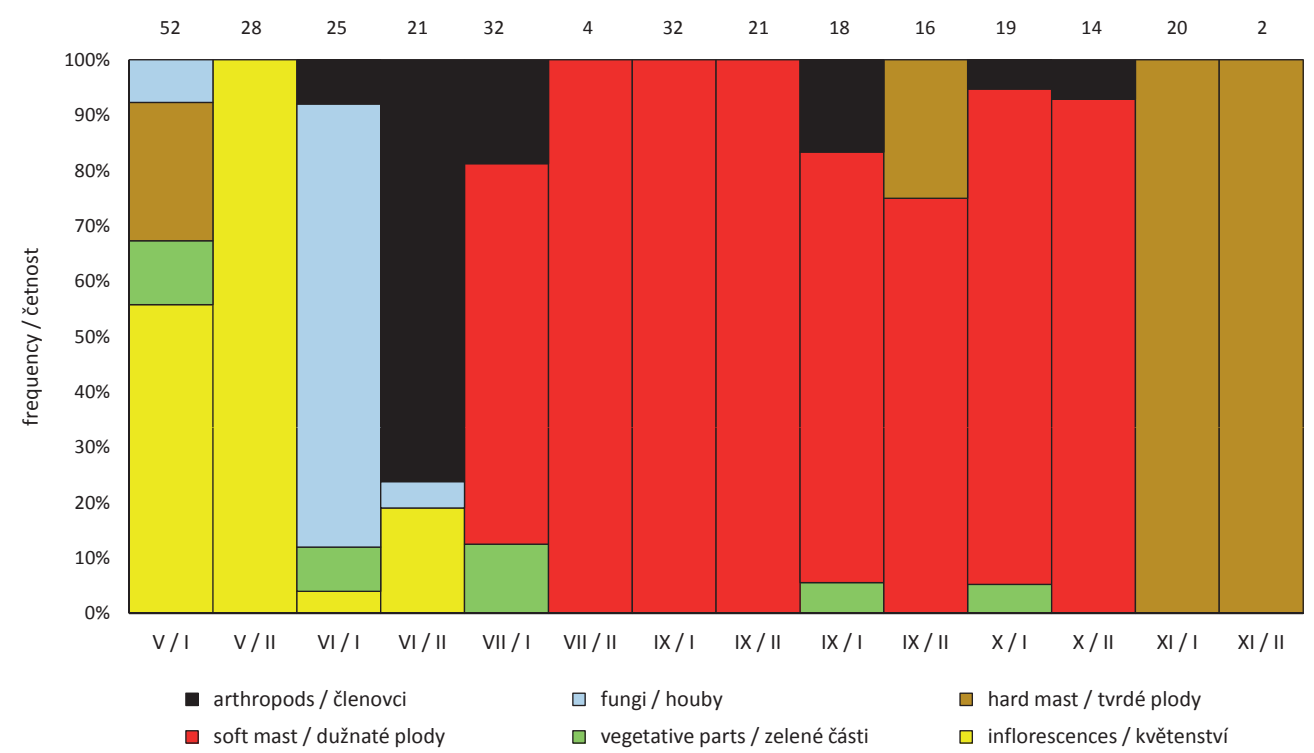

Fig. 3. Seasonal variation in the diet of the hazel dormouse in a species rich habitat in Saxony. Obr. 3. Sesonní proměnlivost v potravě plšíka lískového v druhově bohatém biotopu v Sasku.

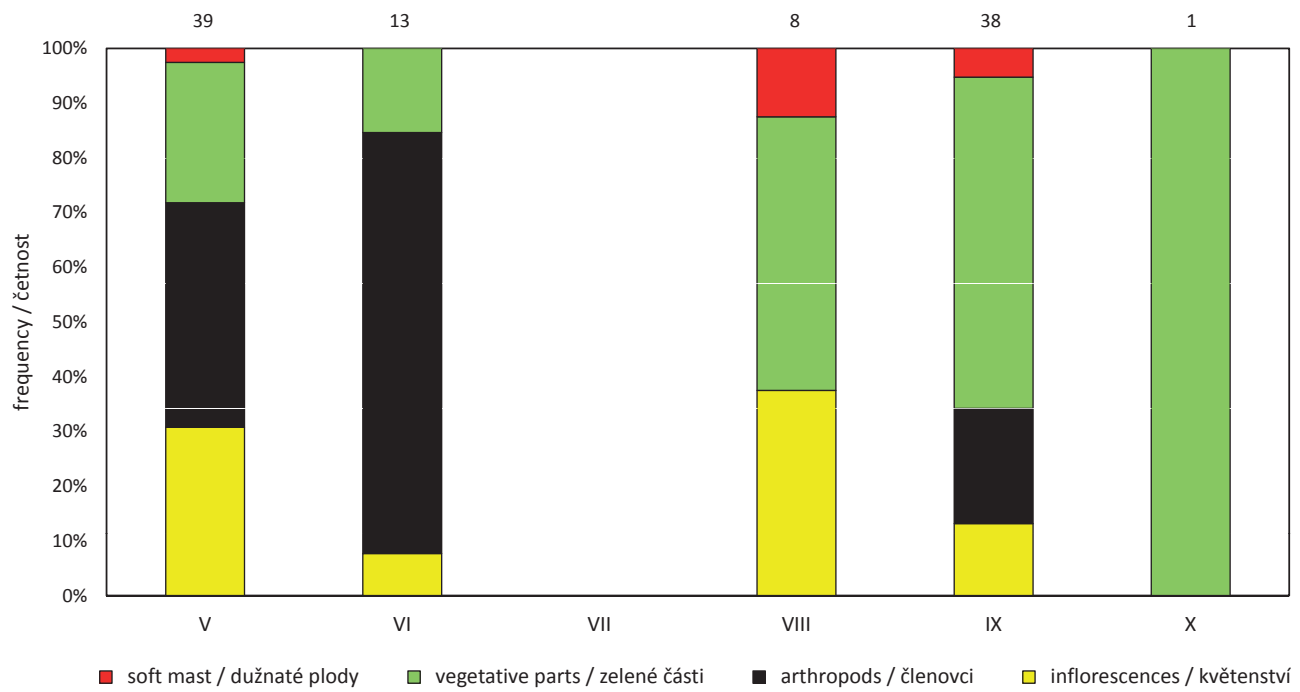

Fig. 4. Seasonal variation in the diet of the hazel dormouse in two spruce dominated forests in Saxony. Obr. 4. Sesonní proměnlivost ve složení potravy plšíka lískového ve dvou saských lesích s převahou smrku ztepilého. 


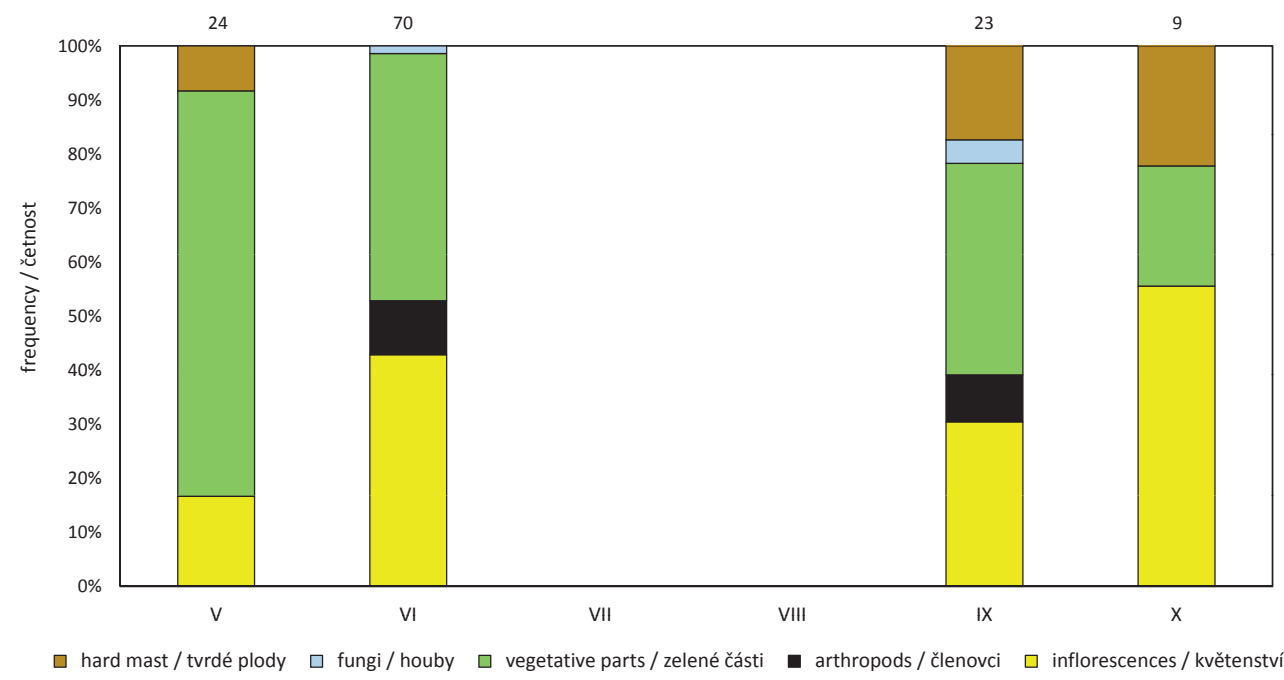

Fig. 5. Seasonal variation in the diet of the hazel dormouse in three beech dominated forests in Saxony and Hesse.

Obr. 5. Sesonní proměnlivost ve složení potravy plšíka lískového ve třech lesích s převahou buku v Sasku a Hesensku.

\section{DISCUSSION}

The results from the reference site $\mathrm{A}$ are similar to the diet described in the hazel dormouse in England and Lithuania (Bright \& Morris 1993, 1996, JušKaitis \& Baltrūnaitė 2013, Chanin et al. 2015, JušKAITIS et al. 2016). With the proof that hazel dormice prey on centipedes, harvesters and spiders, a new aspect of food and prey composition could be shown. The studies previously mentioned also detected chitin remains in hazel dormouse faeces (RICHARDS et al. 1984, ChANIN et al. 2015, JuŠKAITIS et al. 2016). It is possible that other arthropods were hidden amongst these remains. In comparison to bats, arthropods are chewed more thoroughly by hazel dormice, leaving only small pieces of the chitinous skeleton, making the identification more challenging. However, many pieces can clearly be identified under the microscope, at least at the Order level.

It was also possible to distinguish acorns, beech nuts and hazel nuts due to a different pattern in the fat cells that remain in the faeces out of the hard mast. Hazel was sparsely fruiting in 2016 and therefore hazel dormice had to gain fat reserves from different foods, like beech nuts and acorns. Acorns are considered to be of little value for hazel dormice in other parts of its range, like in England or in Italy (Bright \& Morris 1996, ANCILlotTo et al. 2015). However, our results correspond with data from Russia (LozAn 1970, LiHAČEV 1971, AIRAPET'ÂNC 1983), Lithuania (JUŠKAITIS et al. 2016) or Sicily (SARÀ et al. 2001) and show again how flexible the species is.

This pilot study gives a first and interesting insight into the species diet in special habitats. Hazel dormice occurrences in high-grown forests with no flowering and fruiting understorey 
reveal the high adaptability of this species. Consequently, lacking soft mast means that hazel dormice have to substitute for this resource which is the main diet in species-rich woodlands. Contrary to our hypothesis of higher insect percentage in the diet, based on the observations of high importance of insects as diet for hazel dormice (RICHARDS et al. 1984, EDEN 2009, JUŠKAITIS et al. 2016), the animals were able to get along with vegetative material. We can only speculate what hazel dormice actually feed on (buds, leaves or bark) since we found no way to identify the origin of fibres seen under the microscope.

Due to the lack of a caecum all dormice species need high food of high calorific value and find little sustenance in vegetative material (BRIGHT \& MORRIs 1996). With our results we still cannot explain how hazel dormice can survive on such a diet. It is especially unclear considering the distribution of the species. Study sites B and C are situated at higher altitudes. Forests of the same vegetation type in lower altitudes are avoided by hazel dormice while above approximately $650 \mathrm{~m}$ the habitat type is less important for the species distribution (BÜCHNER 2009, WutTKE et al. 2012). In a discriminant analysis for the mountainous area of Saxony (Germany), the altitude was the best explaining factor for the presence of hazel dormouse (WUTTKE et al. 2012). So far, we only know that they can survive by feeding on vegetative plant material in the mountainous habitats, but there is no explanation of why they do not do so in the lowlands. More investigations are necessary to understand how hazel dormice can build up their fat reserves in the spruce forests for hibernation (which is especially long in the mountains). We found no signs of hard mast in the faeces from the spruce forests.

Beech nuts should provide enough hard mast for hazel dormice to fatten, at least in beech masting years. Beech nut crop varies from year to year, which is why the fat dormouse (Glis glis) shows high abundance fluctuations depending on the supply of beech nuts (see e.g. FIETZ et al. 2005, Ruf et al. 2006, LeBL et al. 2010, Morris \& Morris 2010). The abundance of hazel dormice also shows yearly changes in beech-dominated forests, but not as high as in the fat dormouse (S. BüCHNER, unpubl. data).

In summary, this study supports the evaluation by JUŠKAITIS et al. (2016) that hazel dormice are adapted to feed on varying food sources. Further studies over several seasons in habitats with limited plant diversity would be helpful. A uniform data collection would be necessary to compare the sites and to get better knowledge of seasonal factors. Further research should also consider masting versus non-masting years, especially in beech forests, to compare with population metrics.

Hazel dormice often leave only a few droppings in their nest boxes and it could even happen that no faeces at all are found in an occupied nest box. Therefore, considerable effort is needed to get a larger sample size to allow statistical analyses.

\section{SOUHRN}

Abychom mohli porovnat složení potravy plšíka lískového (Muscardinus avellanarius) v druhově bohatém listnatém lese s potravou v druhově chudých lesích, kolektovali jsme pelety trusu ve dvou lesích s převahou smrku ztepilého (Picea abies) a ve třech s převahou buku lesního (Fagus sylvatica) a analysovali složení vzorků s pomocí mikroskopu. V lesích bohatých na dřevinné druhy plšíci na jaře konzumovali zejména květenství, žaludy z předcházejícího roku, houby a členovce, v létě plody/semena s dužinou či měkkým jádrem a na podzim plody s tvrdými jádry. Jak se dalo očekávat, nebyla v potravě z bukového ani smrkového lesa žádná nebo téměř žádná semena s měkkým jádrem anebo dužinou. Hlavními zdroji potravy byla květenství, semena, členovci a poměrně vysoké procento vegetativního rostlinného materiálu. Mezi kořistí plšíka lískového jsme kromě pozůstatků hmyzu osmi rádů také našli pavouky (Araneae), sekáče 
(Opiliones) a stonožky (Chilopoda). Plšíci se mohou vykrmovat na podzim v bukových lesích bukvicemi, ovšem není zcela jasné, jak jsou schopni dosáhnout hibernační hmotnosti v lese s převahou smrku.

\section{Acknow ledgements}

This study formed part of a Master's thesis by N. BRÄSEL. We are particularly grateful to H. ANSORGE for supervising the thesis and for helping us all the time. We are also very thankful to R. JUŠKAITIS and L. BALTRŪNAITE for teaching us the techniques of dormouse food research and for providing continuous support. Special thanks go to J. Anger, J. Pietsch, S. Thoss, J. Schaarschmidt, M. Kraus and S. Malt for collecting faeces.

\section{REFERENCES}

AIRAPET'ÂnC A. E., 1983: Soni [Dormice]. Izdatel'stvo Leningradskogo Universiteta, Leningrad, 189 pp (in Russian).

Ancillotto L., Sozio G. \& Mortelliti A., 2015: Acorns were good until tannins were found: factors affecting seed-selection in the hazel dormouse (Muscardinus avellanarius). Mammalian Biology, 80: 135-140.

Beug H.-J., 2015: Leitfaden der Pollenbestimmung für Mitteleuropa und angrenzende Gebiete. 2. Auflage. Verlag Dr. Friedrich Pfeil, München, 542 pp.

BRIGHT P. W. \& Morris P. A., 1990: Habitat requirements of dormice Muscardinus avellanarius in relation to woodland management in southwest England. Biological Conservation, 54: 307-326.

BRIGHT P. W. \& MoRris P. A., 1996: Why are Dormice rare? A case study in conservation biology. Mammal Review, 26: 157-187.

BüchNer S., 2009: Haselmaus Muscardinus avellanarius (Linnaeus, 1758). Pp.: 263-264. In: Hauer S., Ansorge H. \& Zöphel U. (eds.): Atlas der Säugetiere Sachsens. Sächsisches Landesamt für Umwelt, Landwirtschaft u. Geologie, Dresden, 420 pp.

BÜCHNER S. \& LANG J., 2014: Die Haselmaus (Muscardinus avellanarius) in Deutschland - Lebensräume, Schutzmaßnahmen und Forschungsbedarf. Säugetierkundliche Informationen, 48: 367-377.

Cappers R. T. J., BeKker R. M. \& Jans J. E. A., 2006: Digitaler Samenatlas der Niederlande. URL: www. pflanzenatlas.eu; http://dzn.eldoc.ub.rug.nl/

Chanin P., O'Reilly C., Turner P., Kerslake L., Birks J. \& Woods M., 2015: Insects in the diet of the hazel dormouse (Muscardinus avellanarius): a pilot study using DNA barcoding. Mammal Communications, 1: 1-7.

Eden S., 2009: Living with Dormice. The Common Dormouse: Real Rodent or Phantom of the Ancient Wood. Papadakis Publisher, London \& Winterbourne, $128 \mathrm{pp}$.

Fietz J., Pflug M., Schlund W. \& Tataruch F., 2005: Influences of the feeding ecology on body mass and possible implications for reproduction in the edible dormouse (Glis glis). Journal of Comparative Physiology B, 175: 45-55.

JuŠKaitis R. \& Baltrūnaite L., 2013: Feeding on the edge: the diet of the hazel dormouse Muscardinus avellanarius (Linnaeus 1758) on the northern periphery of its distributional range. Mammalia, 77: 149-155.

JušKaitis R., BALtRŪNAite L. \& KitRytė N., 2016: Feeding in an unpredictable environment: yearly variations in the diet of the hazel dormouse Muscardinus avellanarius. Mammal Research, 61: 367-372.

Lebl K., KÜrbisch K., Bieber C. \& Ruf T., 2010: Energy or information? The role of seed availability for reproductive decisions in edible dormice. Journal of Comparative Physiology B, 180: 447-456.

LiHAČEV G. N., 1971: K biologii orešnikovoj soni [On the natural history of the hazel dormouse]. Trudy Prioksko-Terrasnogo Gosudarstvennogo Zapovednika, 5: 160-175 (in Russian).

Lozan M. N., 1970: Gryzuny Moldavii. Tom 1. Redakcionno-izdatel'skij otdel Akademii nauk Moldavskoj SSR, Kišinev, 168 pp (in Russian). 
Morris P. A. \& Morris M. J., 2010: A 13-year population study of the edible dormouse Glis glis in Britain. Acta Theriologica, 55: 279-288.

Richards C. G. J., White A. C. \& Hurrell E. \& Price F. E. F., 1984: The food of the common dormouse, Muscardinus avellanarius, in South Devon. Mammal Review, 14: 19-28.

Ruf T., Fietz J., Schlund W. \& Bieber C., 2006: High survival in poor years: life history tactics adapted to mast seeding in the edible dormouse. Ecology, 87: 372-381.

Sarà M., Casamento G. \& Spinato A., 2001: Density and breeding of Muscardinus avellanarius L. 1758 in woodlands of Sicily. Trakya University Journal of Scientific Research, Series B, 2: 85-93.

Storch G. 1978: Familie Gliridae Thomas, 1897 - Schläfer. Pp.: 201-280. In: Niethammer J. \& Krapp F. (eds.): Handbuch der Sängetiere Europas. Band 1. Rodentia I (Sciuridae, Castoridae, Gliridae, Muridae). Akademische Verlagsgesellschaft, Wiesbaden, $476 \mathrm{pp}$.

Wuttke N., Büchner S., Roth M. \& Böhme W., 2012: Habitat factors influencing the distribution of the hazel dormouse (Muscardinus avellanarius) in the Ore Mountains, Saxony, Germany. Peckiana, 8: 21-30. 